\title{
THE MESOPROTEROZOIC RHYOLITE OCCURRENCES OF FUERTE OLIMPO AND FUERTE SAN CARLOS, NORTHERN PARAGUAY
}

\author{
CELSO DE BARROS GOMES*, PIERO COMIN-CHIARAMONTI** \& VICTOR FERNANDEZ VELÁZQUEZ *
}

\begin{abstract}
Petrographic and geochemical data make it clear that rocks at the localities of Fuerte Olimpo and Fuerte San Carlos, which lie on the margins of the Paraguay and Apa rivers, respectively, in northern Paraguay, are rhyolites. However, in the Paraguayan geological literature, these sites have been associated to alkaline rocks. Isotopic data for the rhyolites indicate a Precambrian age of $1341 \mathrm{Ma}(1341 \pm 53 \mathrm{Ma}$ and 1343 $\pm 4 \mathrm{Ma}$, respectively) and give almost identical values for the initial ratio ${ }^{87} \mathrm{Sr} /{ }^{86} \mathrm{Sr}$ of $0.71335 \pm 0.00126$ and $0.71215 \pm 0.00008$, respectively. On the basis of these results as well as the distribution of minor and trace elements normalized to primitive mantle, they are probably correlated to the Mesoproterozoic acidic rocks of the Rio Branco Suite occurring in the Jauru Terrain at the SW portion of the Amazon Craton.
\end{abstract}

Resumo Dados petrográficos e geoquímicos demonstram que as rochas aflorando nas localidades de Fuerte Olimpo e Fuerte San Carlos, respectivamente, às margens dos rios Paraguai e Apa, na porção norte do Paraguai, consistem em riólitos. Contudo, na literatura geológica paraguaia, esses lugares têm sido previamente associados à ocorrência de rochas alcalinas. Dados isotópicos indicam para os riólitos uma idade precambriana de $1341 \mathrm{Ma}$ (respectivamente, $1341 \pm 53 \mathrm{Ma}$ e $1343 \pm 4 \mathrm{Ma}$, além de valores similares para a razão inicial ${ }^{87} \mathrm{Sr} /{ }^{86} \mathrm{Sr}$, respectivamente, $0,71335 \pm 0,00126$ e 0,71215 $\pm 0,00008$ ). Com base nesses resultados, bem como na distribuição dos elementos menores e traços normalizados para o manto primitivo, eles são provavelmente correlacionados às rochas ácidas mesoproterozóicas da Suíte Rio Branco que ocorrem no Terreno Jauru, na porção SW do Cráton Amazônico.

Introduction Alkaline rocks are widespread over the Paraguayan territory, the central-eastern region showing the highest concentration of individual bodies. More recently, Velázquez et al. (1996a, 1998), reviewing the alkaline magmatism in the country, have separated the numerous known occurrences into six distinct provinces: Alto Paraguay and Rio Apa, at the northern sector; Amambay, at the northeastern region; Central and Asunción, lying over the centraleastern area; and Misiones, confined to the southernmost tip. In addition to significant differences in mode of occurrence and rock associations, the listed provinces also display a large span of age from Permian-Triassic to Oligocene. The oldest values (250-240 Ma) relate to the Alto Paraguay rocks; the Rio Apa and Amambay provinces represent an Early Cretaceous ( 140 Ma) event, whereas the Central and Misiones provinces are slightly younger $(\sim 128 \mathrm{Ma}$ and $\sim 120 \mathrm{Ma}$, respectively). The newest ages (61-39 Ma) are associated to rocks found in the Asunción area.

Information on the Paraguayan alkaline rocks as a whole are not uniform in spite of concentrated studies since the end of last decade by an international cooperative program involving workers of different countries, mainly from Brazil, Italy and Paraguay. However, considerable progress has already been made, particularly regarding the rock-types from the Alto Paraguay, Central and Asunción provinces. The volume recently edited by Comin-Chiaramonti \& Gomes (1996) brings together all the geochemical data collected in the program. It also provides a general view of the distribution and the main geological and petrographic features of the several alkaline bodies under investigation. More recent sources of information on the Paraguayan alkaline rocks are the papers by Comin-Chiaramonti et al. (1997, 1999).

As a result of the systematic work still in progress, the presence of two occurrences (Fuerte Olimpo and Fuerte San Carlos) in the northern part of the country (Fig. 1), and previously reported in the Paraguayan literature as consisting of alkaline rocks, has not been confirmed on the basis of petrographic and geochemical data.

General description Fuerte Olimpo Fuerte Olimpo, a Paraguayan village located along the margins of the Paraguay river at the northern part of the country, is made up by four lava domes, the largest and highest (over $220 \mathrm{~m}$ ) corresponding to the Cerro Las Tres Marias. The domes are essentially composed by volcanic rocks, sampled in many places (Fig. 2), and are entirely surrounded by Quaternary alluvial sediments. Medium to coarse-grained rock-types of the Precambriam basement also occur not so far away (Fig. 1).

The volcanic rocks are aphyric to weakly porphyritic in texture, the microphenocrysts mainly consisting of quartz and alkali feldspar and plagioclase in minor proportion. They also contain variable amount of microblasts of epidote-chlorite and of micropatches of calcite all set in an aphanitic groundmass. The rocks are classified as rhyolites, but can be also described as ignimbrites owing the presence of fiammae fragments. Textural evidences of metamorphic recrystallization (green schists facies) are recognized in some samples (rheoignimbrites?), and bomb pieces are found included in a few specimens. In earlier studies, they were referred to as forming a porphyritic dyke by DuGraty (1865) and Carnier (1911). On the basis of these descriptions, Livieres \& Quade (1987) listed Fuerte Olimpo as one of its 32 Paraguayan alkaline occurrences.

Fuerte San Carlos Fuerte San Carlos rocks form an isolated small plug, $148 \mathrm{~m}$ high, at the margins of the Apa river in Paraguayan territory. The volcanics are in direct contact with recent deposits, but Eocambriam sediments (predominantly limestones of the Itapucumí Group, equivalent to the Brazilian Corumbá Group) and Precambriam crystalline rocks are found over the whole area (Fig. 1). The old fort was erected over the volcanic rocks, its ruins lying at short distance from the small village of San Carlos (Fig. 3).

The volcanic rocks are aphanitic and weakly porphyritic in texture, the microphenocryst phase mainly represented by alkali feldspar (sanidine); the mineral forms small laths or radiating fibres. The groundmass is crystalline and essentially composed by alkali feldspar, quartz and widely scattered opaque grains. Secondary minerals include abundant chlorite replacing biotite, epidote and carbonates whereas zircon and apatite are found as accessories. The rocks also show small, irregular to round in shape fragments having quartz and feldspar as principal constituents.

Reference to alkaline rocks in Fuerte San Carlos is due to Wiens (1986), who described the presence of aphanitic and porphyritic rocktypes, occasionally with fluidal structure, ranging in composition from trachytes to phonolites.

Geochemistry Major (wt\%) and trace (ppm) abundances were determined by X-ray fluorescence on powder pellets and the values are presented in Table 1. Sr isotopic data for the Fuerte San Carlos rocks are reported in Table 2 whereas the data for the Fuerte Olimpo samples are taken from Velázquez et al. (1996b). All the analyses were performed at the University of Trieste, Italy, using a Philips PW-1400 automated spectrometer.

As shown in Figure 4, the Fuerte Olimpo and Fuerte San Carlos rock-types are basically rhyolitic in composition, which is also confirmed by their high concentrations of $\mathrm{Rb}, \mathrm{Sr}, \mathrm{Zr}$ and $\mathrm{Ba}$. When comparing the both occurrences, the San Carlos volcanics are more enriched in $\mathrm{Ti}, \mathrm{Fe}$ and $\mathrm{Mg}$ in addition to $\mathrm{Zr}, \mathrm{Y}, \mathrm{La}, \mathrm{Ce}$ and $\mathrm{Nd}$. Except for $\mathrm{Rb}, \mathrm{Sr}, \mathrm{Nb}$ and $\mathrm{Ba}$, the trace element contents tend to present lesser dispersion in relation to the major ones.

In spite of some small differences, the lithologies from both associations are compositionally similar, as shown by their minor and trace elements (Fig. 5A) forming two practically coincident distribution curves. This diagram also makes evident the negative anomalies in $\mathrm{K}, \mathrm{Sr}, \mathrm{P}$ and $\mathrm{Ti}$ and the positive ones in $\mathrm{La}-\mathrm{Ce}, \mathrm{Nd}$ and $\mathrm{Zr}$. Sr excluded, the rock-types belonging to the Rio Branco Suite are 


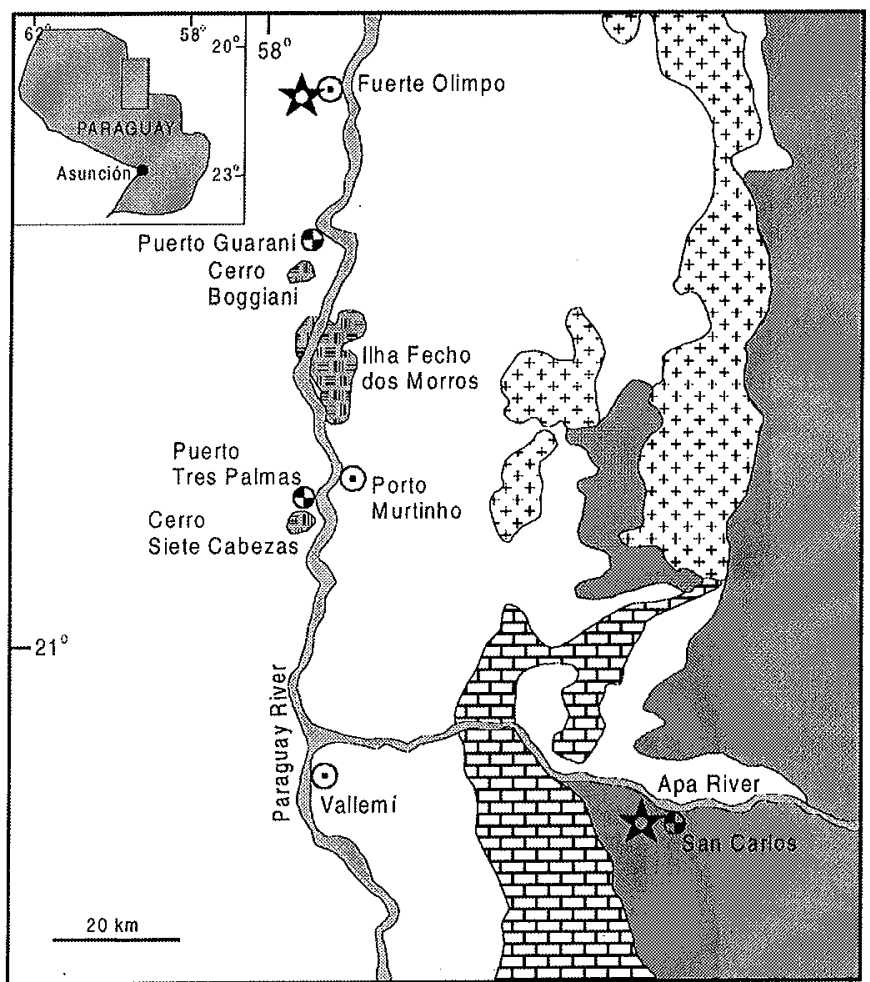

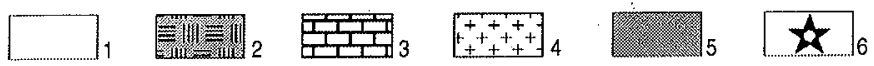

Figure 1 - Geological sketch map of northern Paraguay showing the distribution of main rock-types and the investigated occurrences of Fuerte Olimpo and Fuerte San Carlos. Legends: 1. Quaternary alluvium deposits; 2. Permian-Triassic alkaline rocks; 3. Eocambrian carbonate rocks; 4. Precambrian granitic rocks; 5. Precambrian metamorphic-granitoid basement; 6. Studied Occurrences.

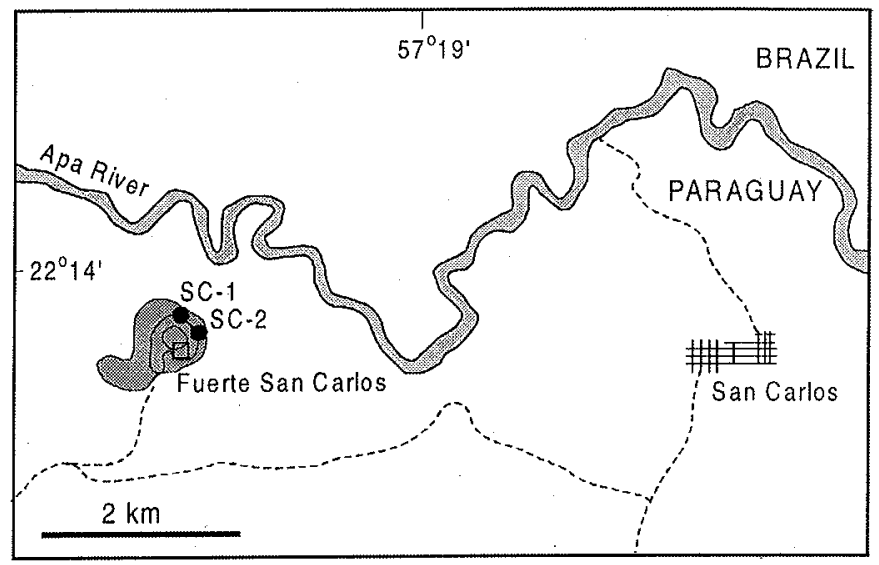

Figure 3-Location of collected samples in the Fuerte San Carlos area.

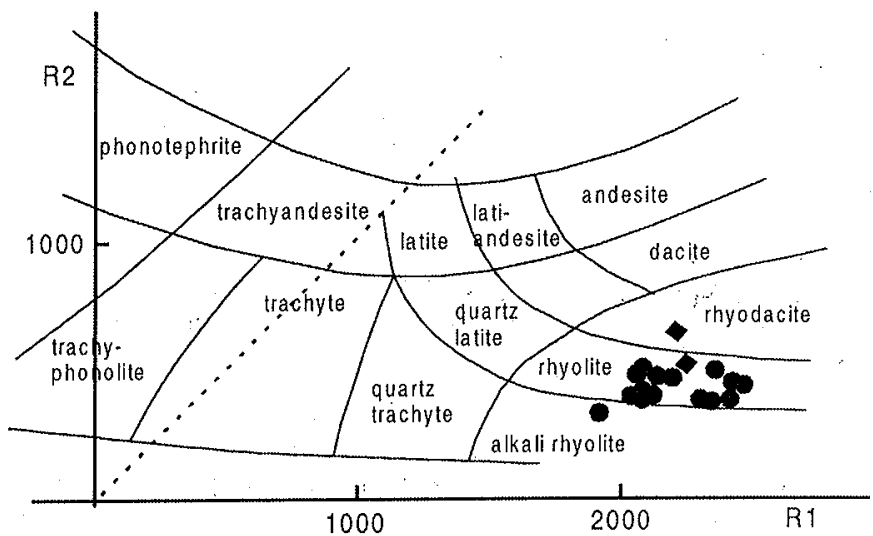

Figure 4-RI-R2 (De La Roche et al., 1980) classification diagram for the Fuerte Olimpo (full circle) and Fuerte San Carlos (full dianond) volcanic rocks.

Table 1 - Chemical analyses for major (wt\%) and trace (ppm) elements of Fuerte Olimpo (FO) and Fuerte San Carlos (SC) volcanic rocks. Also shown are the RI and $R 2$ values (De La Roche et al., 1980).

\begin{tabular}{|c|c|c|c|c|c|c|c|c|c|c|c|c|c|c|c|c|c|}
\hline & & & & & & & & & & & & & & & & & \\
\hline & $\mathrm{D}-23$ & 0.20 & $0-13$ & 0.10 & $\mathrm{FO}-17$ & $\mathrm{FO}-19 \mathrm{~A}$ & $\mathrm{FO}-14$ & FO-15: & $\mathrm{FO}-198$ & $\mathrm{FO}-22$ & $\mathrm{FO}-16$ & $F O-12$ & $F O-21$ & FO-11 & FO-18: & SC-1 & \\
\hline $\mathrm{O}_{2}$ & 74,69 & 73,31 & 3,15 & 72,99 & 72,84 & 72,64 & 72,45 & 72,31 & 71,95 & $1,1,87$ & 71,85 & 1,12 & 0,95 & 0,89 & 0,74 & $3,6 !$ & 77,6 \\
\hline $\mathrm{IO}_{2}$ & 0,23 & 0,30 & 0,23 & 0,31 & 0,28 & 0,34 & 0,24 & 0,31 & 0,23 & 0,35 & 0,32 & 0,23 & 0,39 & 0,31 & 0,35 & 0,49 & 0,49 \\
\hline $\mathrm{I}_{2} \mathrm{O}_{3}$ & 13,09 & 14,40 & 14,52 & 14,55 & 14,27 & 14,09 & 14,40 & 14,10 & 14,82 & 14,36 & 14,64 & 14,46 & 14,68 & 14,06 & 14,47 & 13,97 & 14,21 \\
\hline $\mathrm{Fe}_{2} \mathrm{O}_{3}$ & 0,71 & 0,59 & 1,02 & 0,71 & 0,88 & 1,12 & 1,01 & 0,99 & 1,04 & 1.14 & 1,12 & 0,88 & 1,36 & 0,90 & 1,08 & 2,23 & 2,28 \\
\hline $\mathrm{FeO}$ & 0,78 & 0,90 & 0.75 & 0.74 & 0,76 & 0,81 & 0,87 & 0,82 & 0,32 & 0,95 & 0,93 & 1,01 & 1.09 & 1,00 & 1,26 & 1,12 & 1,1 \\
\hline no & 0,03 & 0,08 & 0.08 & 0,06 & 0,07 & 0,09 & 0,10 & 0,09 & 0,02 & 0,09 & 0.11 & 88 & 0,10 & .093 & 0,10 & 0,06 & 0,0 \\
\hline 190 & 20 & 0,55 & 0,55 & 0,48 & 0,57 & 0,58 & 0,42 & 0,59 & 0,04 & 0,8 & 0,67 & 65 & 3 & 0,63 & 0,82 & 1,83 & 1,8 \\
\hline $\mathrm{CaO}$ & & 0,79 & 21 & 0,50 & 0,63 & 1,40 & 1,490 & 93 & & 1. & 7 & 31 & 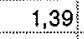 & 0,75 & 1,46 & 1,08 & 1,8 \\
\hline & & 4,84 & 28 & 4,72 & 5,53 & 5,38 & 4,30 & 5,60 & 3,67 & $5,11]$ & 06 & 3,13 & 4,90 & .94 & 5,17 & 3,24 & 6. \\
\hline $\mathrm{K}_{2} \mathrm{O}$ & 5,26 & 3,50 & 3.45 & 3,74 & 2,94 & 2,65 & 3,57 & 2,97 & 45 & 3,09 ; & 3,35 & 3,80 & 3,48 & 3,53 & 2,95 & 4,37 & 4,9 \\
\hline $\mathrm{P}_{2} \mathrm{O}_{5}$ & 0,04 & 0,08 & 0,07 & 0,08 & 0,07 & 0,09 & 0,07 & 0,09 & 0,05 & 0,10 & 0,08 & 0,07 & 0,10 & 0,10 & 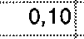 & 0,0 & 0,08 \\
\hline $\mathrm{LOI}$ & 0,57 & 0,63 & 0,63 & 1,06 & 1,04 & 0,7 & 0,87 & 1,08 & 0,66 & 0,88 & 0,99 & 0,90 & 0,71 & 0,98 & 1,46 & 3,12 & 2,2 \\
\hline Total & 99,71 & 99,97 & 99,94 & 99,94 & 99,88 & 99,89 & 99,79 & 99,88 & 99,94 & 99,88 & 99,89 & 98,24 & 99,88 & 98,18 & 99,96 & 00,25 & 99,7 \\
\hline & & & & & & & & & & & & & & & & & \\
\hline $\mathrm{Cr}$ & $<1$ & $<1$ & $<1$ & $<1$ & $<1$ & $<1$ & $<1$ & $<1$ & $<1$ & $<1$ & $<1$ & $<1$ & $<1$ & $<1$ & $<1$ & $<1$ & \\
\hline $\mathrm{Ni}$ & 6 & 4 & 7 & 6 & 5 & 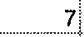 & 9 & 6 & 5 & 3 & 7 & 6 & 8 & 1 & 4 & $<1$ & \\
\hline $\mathrm{Bb}$ & 139 & 118 & 128 & 144 & 114 & 94 & 141 & 108 & 154 & 100 & 138 & 178 & 112 & 126 & 96 & 179 & 205 \\
\hline $\mathrm{Sr}$ & 211 & 192 & 187 & 146 & 188 & 172 & 354 & 206 & 179 & 265 & 133 & 391 & 227 & 199 & 188 & 141 & 190 \\
\hline $\mathrm{zr}$ & 133 & 184 & 212 & 208 & 182 & 189 & 208 & 181 & 179 & 194 & 22 & 218 & 198 & 190 & 193 & 285 & 319 \\
\hline$y$ & 36 & 34 & 34 & 39 & 34 & 29 & 32 & 32 & 42 & 32 & 36 & 33 & 31 & 32 & 32 & 66 & 49 \\
\hline Nh & 17 & 14 & 14 & 15 & 15 & 13 & 15 & 14 & 17 & 14 & 16 & 15 & 14 & 14 & 14 & 16 & 16 \\
\hline Ba & 1716 & 1300 & 1003 & 1229 & 1136 & 115 & 1054 & 1156 & 2013 & 1274 & 1117 & 1192 & 486 & 1368 & 1173 & 928 & 1250 \\
\hline La & 48 & 48 & 39 & 47 & 46 & 46 & 37 & 41 & 52 & 47 & 52 & 44 & 50 & 48 & 46 & 70 & 94 \\
\hline $\mathrm{Ce}$ & 98 & 101 & 83 & 93 & 98 & 90 & 80 & 95 & 102 & 97 & 107 & 88 & 107 & 96 & 102 & 136 & 169 \\
\hline $\mathrm{Nd}$ & 49 & 43 & 39 & 46 & 44 & 46 & 40 & 44 & 56 & 45 & 51 & 37 & 49 & 45 & 45 & 61 & \\
\hline & & & & 76 & $1 / 4:$ & 74 & 435 & 2103 & 1971 & 2214 & & & & & & 208 & \\
\hline 12 & 301 & 394 & 442 & 363 & $3 / 6$ & 455 & 463 & 406 & 296 & 454 & 403 & 456 & 473 & 387 & 481 & 473 & \\
\hline
\end{tabular}


Table 2 - Isotopic data for the Fuerte Olimpo and Fuerte San Carlos rhyolites. Values for the first occurrence are from Velazquez et al. (1996b).

\begin{tabular}{lccc}
\hline & $\mathrm{Rb}$ & $\mathrm{Sr}$ & ${ }^{6} \mathrm{Sr}^{36} \mathrm{Sr}$ \\
\hline \multicolumn{2}{c}{ Fuerte Olimpo } \\
\hline FO-10 & 136 & 141 & $0.76652(10)$ \\
FO-16 & 122 & 134 & $0.76504(8)$ \\
FO-18 & 102 & 198 & $0.74097(9)$ \\
FO-19 & 94 & 238 & $0.73573(6)$ \\
FO-20 & 124 & 208 & $0.74737(9)$ \\
FO-22 & 100 & 265 & $0.72983(1)$ \\
Fuerte San Carlos & & \\
AP-1 & 194.9 & 160.7 & $0.77064(2)$ \\
AP-2 & 201.4 & 158.7 & $0.77255(2)$ \\
AP-4 & 198.4 & 185.8 & $0.77121(3)$ \\
AP-5 & 194.1 & 155.4 & $0.77191(2)$ \\
AP-6 & 206.4 & 190.8 & $0.76949(2)$ \\
SC-1 & 179 & 141 & $0.78381(12)$ \\
SC-2 & 205 & 190 & $0.77251(11)$ \\
SC-2 & 408 & 97 & $0.95205(15)$ \\
\hline
\end{tabular}
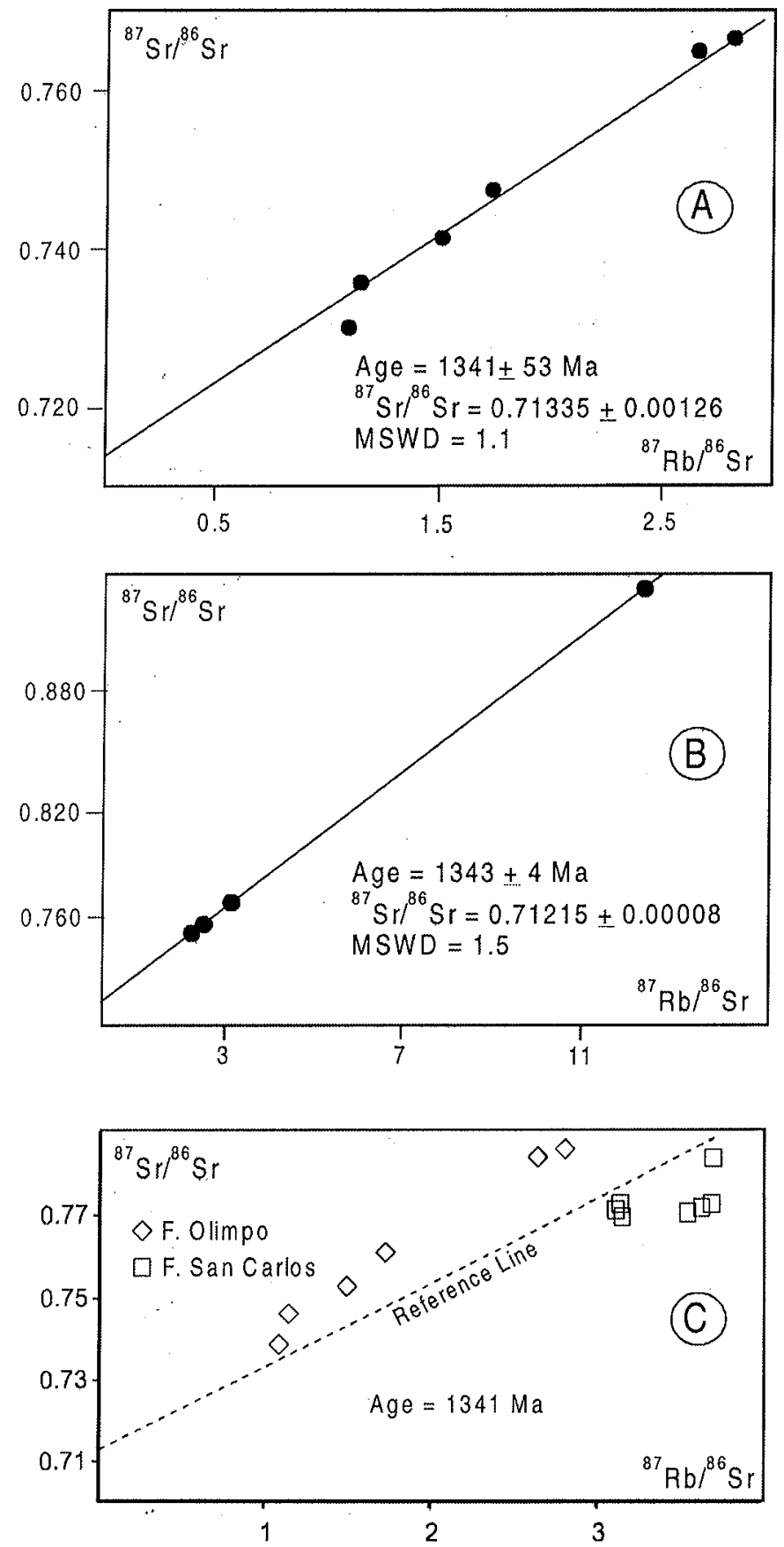

Figure 6-Isochrons for the Fuerte Olimpo (A) and Fuerte San Carlos (B) volcanic rocks, indicating $R b / S r$ ages of $134 \mathrm{I}+53 \mathrm{Ma}$ and $1343 \pm 4 \mathrm{Ma}$ respectively. A reference line for $1341 \mathrm{Ma}$ is also shown $(C)$.

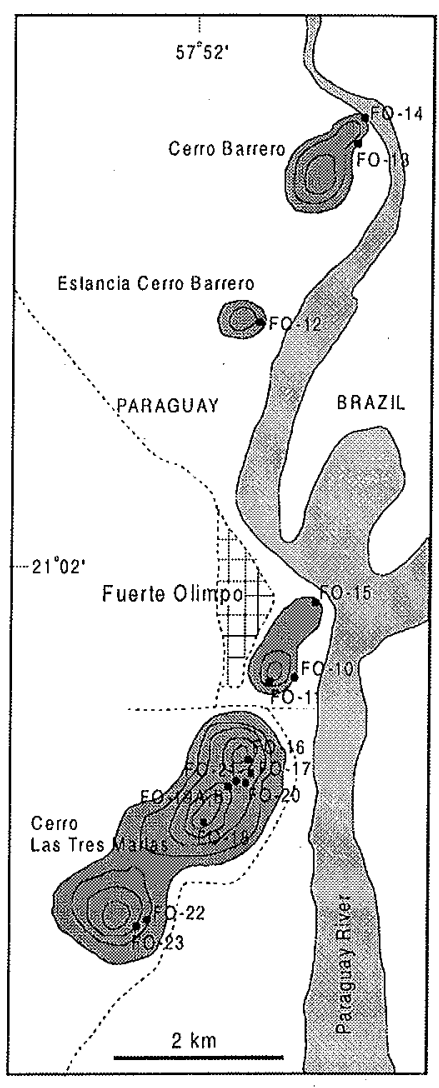

Figure 2 -Location of collected samples in the Fuerte Olimpo area.

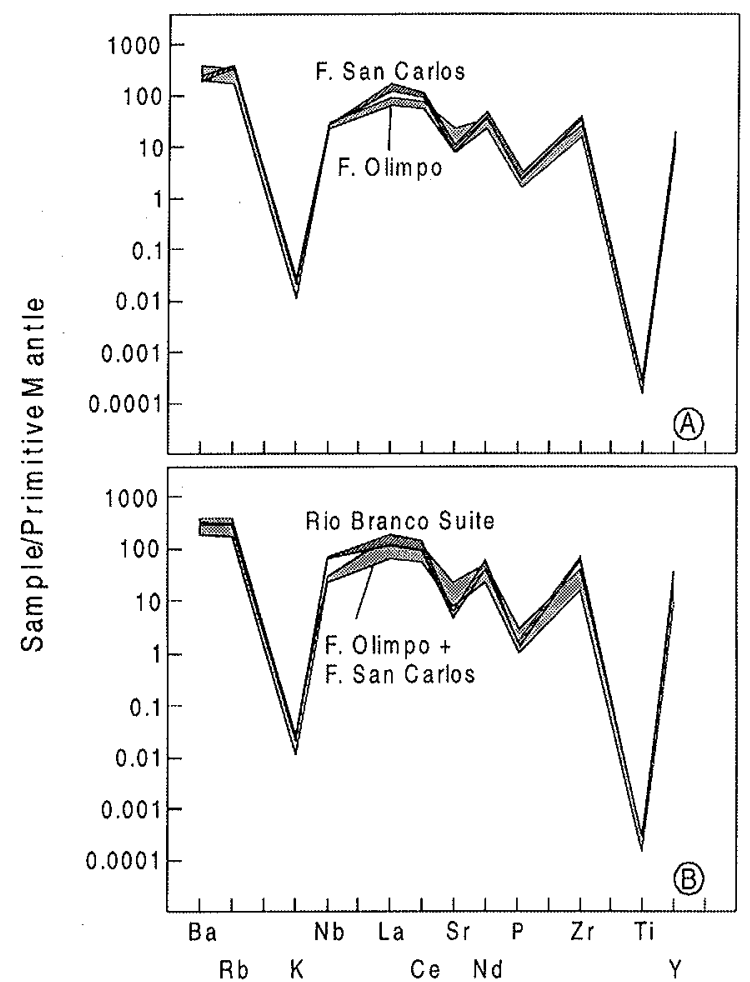

Figure 5-Primordial mantle-normalized incompatible elements diagrant for the Fuerte Olimpo and Fuerte San Carlos volcanic rocks (A). For comparison, the variation fields for intrusive silicic rocks of the Rio Branco Suite in the Amazon Craton (B). Normalizing values are from Sun \& McDonough (I989). 
in general slightly more enriched than the Paraguayan ones, despite the similar behaviour (Fig. 5B).

Initial ratio ${ }^{87} \mathrm{Sr} /{ }^{86} \mathrm{Sr}$ values for the Fuerte Olimpo and Fuerte San Carlos volcanics are almost identical, $0.71335 \pm 0.00126$ and $0.71215 \pm 0.00008$, whereas isochron diagrams point to $\mathrm{ab} / \mathrm{Sr}$ age of $1341 \mathrm{Ma}(1341 \pm 53 \mathrm{Ma}$ and $1343 \pm 4 \mathrm{Ma}$, respectively). On the other hand, an $\mathrm{U} / \mathrm{Pb}$ age on zircon of $1423 \pm 2 \mathrm{Ma}$ is reported for the Rio Branco Suite (Geraldes, 2000).

Conclusive remarks Volcanic rock-types of rhyolitic composition are recognized in the places of Fuerte Olimpo and Fuerte San Carlos at the northern portion of Paraguayan territory. They are entirely surrounded by recent sediments, but granitic and metamorphic rocks of the crystalline basement are also found over the whole area. Geochemical and isotopic data indicate for the volcanics a Precambrian age (1341 Ma), $\mathrm{Sr}_{\mathrm{i}}$ values of 0.71215-0.71335 and a similar pattern for incompatible elements compared to the Mesoproterozoic acidic lithologies of the Rio Branco Suite cropping out in the Jauru Terrain at the SW portion of the Amazon Craton.

Acknowledgements

Thanks are due to Fapesp (Proc. $97 /$ 01210-4) for financial support and to Dr. Ian McReath for reviewing the manuscript.

\section{References}

Carnier, K. 1911. Reisen in Mato Grosso und Paraguay. Mitteilungen Geologische Gesellenschaft 61:18-44.

Comin-Chiaramonti, P. \& Gomes, C.B. 1996. Alkaline magmatism in the Central-Eastern Paraguay. Relationships with coeval magmatism in Brazil. São Paulo, Edusp-Fapesp. 432p.

Comin-Chiaramonti, P. Cundari, A Piccirillo, E.M., Gomes, C.B., Castorina, F., Censi, P. De Min, A., Marzoli, A., Speziale, S., Velázquez, V.F. 1997. Potassic and sodic igneuos rocks from Eastern Paraguay: their origin from the lithospheric mantle and genetic relationships with the Paraná flood tholeites. Joumal of Petrology, 38:495 528 .

Comin-Chiaramonti, P., Cundari, A., DeGraff, J.M., Gomes, C.B., Piccirillo, E.M. 1999 Early Cretaceous-Tertiary magmatism in Eastern Paraguay (Western Paraná Basin) geological, geophysical and geochemical relationships. Journal of Geodynamics, 28:375-391.

De La Roche H. Leterrier, J., Grandclaude, P., Marchal, M. 1980. A classification of volcanic and plutonic rocks using R1-R2 diagram and major-element analyses. Its relationships with current nomenclature. Chemical Geology', 29:183-210.

DuGraty, A. 1865. La République de Paraguay. 2d ed., C. Murquardt, Bruxelles, 407p.

Du

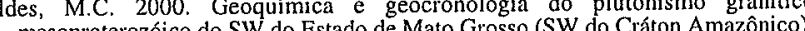
mesoproterozóico do SW do Estado de Mato Grosso (SW do Cráton Amazo Táne de Doutoramento, 193p.
Livieres, R.A. \& Quade, H. 1987. Distribución regional y asentamiento tectónico de los complejos alcalinos del Paraguay. Zentralblatt für Geologie und Palaeontologie Teil I, (7/8):791-805.

Sun, S-S \& McDonough, W.F. 1989. Chemical and isotopic systematics of oceanic basalts. In: A.D. Saunders \& M.J. Norry (eds.) Magmatism in the Ocean Basins. Geol. Soc Sp. Publ., 42:313-345.

Velázquez, V.F., Gomes, C.B., Orué, D., Comin-Chiaramonti, P. 1996a. Magmatismo alcalino do Paraguai: uma revisão e atualização das províncias. Boletim IG-USP, Séric Científica, 27:61-79.

Velázquez, VF Gomes C.B. Teixeira, W. Comin-Chiaramonti, P. 1996b. Contribution to the geochronology of the Permo-Triassic alkaline magmatism of the Alto Paraguay the geochronology of the Permo-Triassic alkaline magmatis.

Velázquez V.F. Riccomini, C. Gomes, C.B., Figueredo, L., Figueredo, C. 1998. Relaçōes Puez, V.F., Riccomini, C., Gomes, C.B., Figueredo, L., Figueredo, C.

tectônicas do magmatismo aicalino do Paraguai Oriental. Revisurellen entwicklung F. 1986. Zur lithostratigraphischen, petrographischen und strukurellen entwicklung
des Rio Apa-Hochlandes, Nordost-Paraguay. Clausthaler Geowissenschaftliche Dissertationen, 19:280p.

Manuscrito NB-23

Recebido em 30 de outubro de 2000

Revisão dos autores em 30 de novembro de 2000 Revisão aceita em 15 de dezembro de 2000 